\title{
Spheniscidite, a new phosphate mineral from Elephant Island, British Antarctic Territory
}

\author{
M. J. Wilson AND D. C. Bain \\ Department of Mineral Soils, the Macaulay Institute for Soil Research, Craigiebuckler, Aberdeen
}

\begin{abstract}
A BSTRACT. Spheniscidite is a new phosphate mineral occurring in a soil profile in an area of nesting penguins on Elephant Island. It is the $\mathrm{NH}_{4}$-dominant analogue of leucophosphite and has the formula $\left(\mathrm{NH}_{4}, \mathrm{~K}\right)\left(\mathrm{Fe}^{3+}, \mathrm{Al}\right)_{2}$ $\left(\mathrm{PO}_{4}\right)_{2}(\mathrm{OH}) \cdot 2 \mathrm{H}_{2} \mathrm{O}$. It is monoclinic, $P 2_{1} / n$ with unit cell parameters $a=9.75, b=9.63, c=9.70 \AA, \beta=102^{\circ} 34^{\prime}$, and $Z=4$. The strongest $X$-ray lines are $6.79(100)$ 5.99(90), 3.05(45), 7.62(40) $\AA$. Spheniscidite is thought to have formed by the interaction of ammonium phosphate solutions from penguin guano with micaceous and chloritic minerals in the soil. The name is for Sphenisciformes, the order name for penguins, and has been approved by the IMA Commission on New Minerals and Mineral Names.
\end{abstract}

KEYWORDS: spheniscidite, phosphate minerals, new minerals, Elephant Island, Antarctica.

A DESCRIPTION of some of the properties and the occurrence of an ammonium-rich leucophosphite has already been published (Wilson and Bain, 1976) but the mineral has since been recognized as a new species-spheniscidite-by the IMA Commission on New Minerals and Mineral Names. The purpose of this note is to list the data essential for identification of this mineral and to provide supplementary information on its properties and characteristics.

The mineral occurs in an ornithogenic soil (associated with a penguin rookery) developed on till derived from dark grey and green chloritic phyllites on Elephant Island, British Antarctic Territory. The island is at the eastern end of the South Shetland Islands, about 500 miles $(800 \mathrm{~km})$ southeast of Cape Horn, and the soil profile was sampled by $\mathrm{Mr}$ R. M. G. O'Brien at Chinstrap Camp on the western side of the island $\left(61^{\circ} 10^{\prime} \mathrm{S}\right.$., $54^{\circ} 45^{\prime}$ W.). The spheniscidite occurs as finegrained, brown aggregates concentrated mainly in the $75-2000 \mu \mathrm{m}$ fraction from which it was separated electromagnetically.

$X$-ray data. The X-ray powder pattern is essentially the same as that of the leucophosphite from the Sapucaia pegmatite (Lindberg, 1957) and using the unit cell parameters given for this mineral many of the lines in the pattern of spheniscidite can be

(C) Copyright The Macaulay Institute for Soil Research reasonably well indexed (Table I). The powder pattern is also very close to that of the synthetic compound $\mathrm{Fe}_{2} \mathrm{~K}\left(\mathrm{PO}_{4}\right)_{2} \mathrm{H}_{2} \mathrm{O}$ listed by Lehr et al. (1967). Using the unit cell parameters given for this compound as starting parameters $(a=9.76, b=$ $9.65, c=9.70 \AA, \beta=102^{\circ} 54^{\circ}$, Space Group $P 21 / n$ ) and only those spacings in the spheniscidite powder pattern with single indices, a least-squares refinement yielded the following unit cell parameters for spheniscidite $a=9.75(1), b=9.63(2), c=9.70(1) \AA$, $\beta=102^{\circ} 34(7)^{\prime}, \mathrm{V}=888(2) \AA^{3}$.

Chemical data. The mineral was analysed by $\mathrm{X}$-ray fluorescence spectrometry using the fusion method and correction procedures of Norrish and Hutton (1969). The presence of ammonium was indicated by the characteristic infra-red absorption bands at 3.2 and $7.0 \mu \mathrm{m}$ (Arlidge $e t$ al., 1963) and the amount of $\left(\mathrm{NH}_{4}\right)_{2} \mathrm{O}$ calculated from the quantity of total $\mathrm{N}$ measured on pyrolysis using a HewlettPackard CHN 185 analyser. After correction for $9.93 \% \mathrm{SiO}_{2}$ and $0.91 \% \mathrm{TiO}_{2}$ which are present as impurities, the resultant analysis is $\mathrm{Al}_{2} \mathrm{O}_{3} 9.33$, $\mathrm{Fe}_{2} \mathrm{O}_{3}$ (total iron) $30.10, \mathrm{CaO} 0.50, \mathrm{MgO} 0.30, \mathrm{~K}_{2} \mathrm{O}$ 4.45, $\mathrm{Na}_{2} \mathrm{O}$ n.d., $\left(\mathrm{NH}_{4}\right)_{2} \mathrm{O} 3.27, \mathrm{P}_{2} \mathrm{O}_{5} 32.42, \mathrm{H}_{2} \mathrm{O}^{-}$ $\left(105^{\circ} \mathrm{C}\right) 5.84, \mathrm{H}_{2} \mathrm{O}^{+}\left(105-1000^{\circ} \mathrm{C}\right) 13.79$, total $100.0 \%$. This yields the following empirical formula:

$\left(\left(\mathrm{NH}_{4}\right)_{0.55} \mathrm{~K}_{0.41} \mathrm{Ca}_{0.04} \mathrm{Mg}_{0.03}\right)_{\Sigma 1.03}$ $\left(\mathrm{Fe}^{2+}{ }_{1.20} \mathrm{Al}_{0.80}\right)_{\Sigma 2.00} \mathrm{P}_{2} \mathrm{O}_{8.05}(\mathrm{OH}) \cdot \mathrm{H}_{2} \mathrm{O}$

on the basis of $\mathbf{P}=2$, with excess iron and water. Thus, spheniscidite is the $\mathrm{NH}_{4}$-dominant analogue of leucophosphite and the name is for material with $\mathrm{NH}_{4}>\mathrm{K}$ and $\mathrm{Fe}^{3+}>\mathrm{Al}$.

The mineral is soluble in acids but insoluble in water.

Thermal data. The DTA curve (fig. 1) shows two marked endothermic peaks at 110 and $195^{\circ} \mathrm{C}$ associated with loss of water of crystallization, and two exothermic reactions at 538 and $572{ }^{\circ} \mathrm{C}$ which are presumed to be due to decomposition and recrystallization.

Optical and physical properties. Optical properties could not be determined in detail because 


\begin{tabular}{|c|c|c|c|c|c|c|c|}
\hline$I / I_{0}$ & $\underline{d}_{\text {meas }}$ & $\underline{\mathrm{hkl}}$ & & & $I / \underline{I}_{0}$ & $\underline{d}_{\text {meas }}$ & $\underline{\mathrm{nkl}}$ \\
\hline 40 & 7.62 & $\overline{1} 01$ & & & 5 & 2.488 & 231,132 \\
\hline 100 & 6.79 & 110 & & & 5 & 2.439 & $321, \quad 313$ \\
\hline 30 & 6.09 & 101 & & & 5 & 2.376 & 400 \\
\hline 90 & 5.99 & $\overline{1} 11$ & & & 5 & 2.346 & $\overline{1} 14$ \\
\hline 35 & 4.75 & 020. & 200. & 002 & 5 & 2.265 & $\overline{1} 33$ \\
\hline 5 & 4. $48^{*}$ & & & & 5 & 2.178 & \\
\hline 35 & 4.26 & 021. & 210 & & 5 & 2.145 & \\
\hline 10 & 4.06 & $\overline{1} 21$ & & & 10 & 1.994 & \\
\hline 20 & 3.78 & $\overline{2} 02$, & 121 & & 5 & 1.957 & \\
\hline 5 & 3.65 & 211 , & 112 & & 10 & 1.923 & \\
\hline 5 & 3.53 & $\overline{2} 12$ & & & 5 & 1.893 & \\
\hline 35 & 3. $35 \mathrm{~B}$ & $\overline{2} 21$, & 122 & & 5 & 1.816 & \\
\hline 15 & $3.22 \mathrm{~B}$ & $\overline{3} 01$ & & & 5 & 1.785 & \\
\hline 45 & 3.053 & $\overline{3} 11$, & 202 & $\overline{1} 13$ & 5 & 1.748 & \\
\hline 20 & 2.983 & $\overline{2} 22$ & & & 5 & 1.700 & \\
\hline 20 & 2.902 & 212 & & & 5 & 1.657 & \\
\hline 30 & 2.825 & 131. & 301. & 103 & 5 & 1.619 & \\
\hline 25 & 2.657 & 230. & 032 & & 5 & 1.586 & \\
\hline 5 & 2.577 & 222 & & & 5 & 1.561 & \\
\hline \multirow[t]{2}{*}{5} & 2.534 & $\overline{3} 03$ & & & 5 & 1.526 & \\
\hline & & & & & 5 & 1.495 & \\
\hline
\end{tabular}

* Unidentified impurity

of the very fine grain size of the material, but spheniscidite is colourless in thin section, refractive indices are close to 1.7 and birefringence is moderate. Optical properties are, however, given

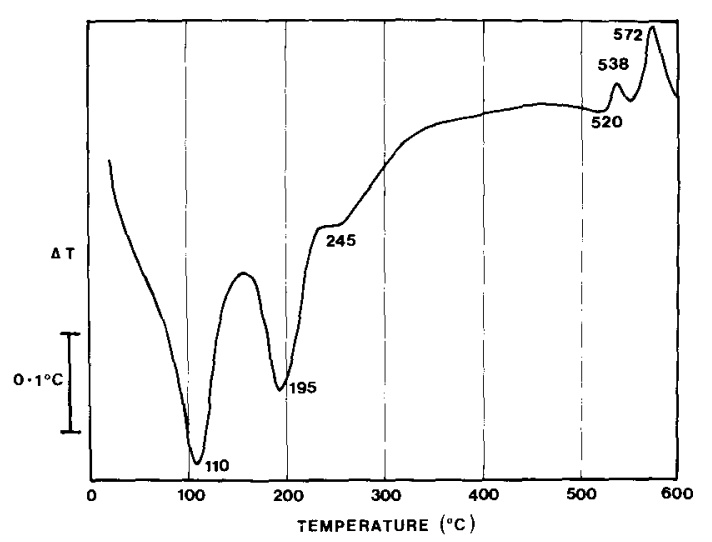

FIG. 1. DTA curve of spheniscidite obtained in $N_{2}$ atmosphere. by Lehr et al. (1967) for the closely comparable synthetic phosphate $\mathrm{Fe}_{2} \mathrm{~K}\left(\mathrm{PO}_{4}\right)_{2} \mathrm{OH} \cdot 2 \mathrm{H}_{2} \mathrm{O}$. This compound occurs in stout prisms, elongated along $c$ and with excellent cleavage on (100). It has refractive indices of $\alpha=1.706, \beta=1.724$ and $\gamma=1.741$, is biaxial $(+)$ and has $2 \mathrm{~V}=81^{\circ}$. The OAP is normal to (010) with $\mathrm{X}=b$. Spheniscidite is brown in colour, has an earthy lustre and is very soft. Its calculated density based on its empirical formula is $2.71 \mathrm{~g} / \mathrm{cm}^{3}$.

Paragenesis. Spheniscidite occurs as fine-grained brown aggregates which are translucent in thin section where phyllitic rock fragments are often surrounded by a reaction rim of the mineral. The soil profile is in an area occupied by nesting chinstrap penguins and it would appear that the spheniscidite forms by the interaction of ammonium phosphate solutions from the penguin guano with the micaceous and chloritic minerals in the soil. An extensive range of phosphate minerals has since been recorded in ornithogenic soils in Antarctica including struvite, hydroxyapatite, taranakite, and minyulite (Tatur and Barczuk, 1985).

Name. The name spheniscidite is derived from 
Sphenisciformes, the order name for penguins. The original material is now stored at the Macaulay Institute for Soil Research but will be donated to the British Museum (Natural History).

Acknowledgements. The authors are grateful to Dr J. A. Mandarino, Department of Mineralogy and Geology, Royal Ontario Museum, Toronto, for his help and encouragement and for determining the unit cell parameters by a least-squares refinement program.

\section{REFERENCES}

Arlidge, E. Z., Farmer, V. C., Mitchell, B. D., and Mitchell, W. A. (1963) J. Appl. Chem. 13, 17-27.
Lehr, J. R., Brown, E. H., Frazier, A. W., Smith, J. P., and Thrasher, R. D. (1967) Crystallographic Properties of Fertilizer Compounds. Chem. Eng. Bull. No. 6. Tennessee Valley Authority.

Lindberg, M. L. (1957) Am. Mineral. 42, 214-21.

Norrish, K., and Hutton, J. T. (1969) Geochim. Cosmochim. Acta, 33, 431-53.

Tatur, A., and Barczuk, A. (1985) Antarctic Nutrient Cycles and Food Webs. (W. R. Siegfried, P. R. Condy, and R. M. Laws, eds.). Springer-Verlag, Berlin, Heidelberg.

Wilson, M. J., and Bain, D. C. (1976) Am. Mineral. 61, 1027-8.

[Manuscript received 22 November 1985] 